\title{
Investigating Mixed-Ability Teaching in Taiwanese Primary Schools
}

\author{
Ling-Ying Huang ${ }^{1}$ \\ ${ }^{1}$ Graduate School of Education, University of Exeter, UK \\ Correspondence: Ling-Ying, Huang Graduate School of Education, University of Exeter, UK. E-mail: \\ linhuang216@hotmail.com
}

Received: February 20, 2014 Accepted: March 20, 2014 Online Published: April 28, 2014

doi:10.5539/ies.v7n5p85

URL: http://dx.doi.org/10.5539/ies.v7n5p85

\begin{abstract}
In 2001, Taiwan reformed English language teaching in primary schools, and a mixed ability approach was taken as an organisational method for this. Many teachers claim that they encounter numerous difficulties in catering for different needs because of the large number of differences between students. However, the debate and comparisons between the traditional streamed approach and the current mixed ability approach continues in Taiwan. This study seeks to explore Taiwanese English teachers' attitudes towards MAT (mixed ability teaching) and MAC (mixed ability class) in primary schools. To do this, a questionnaire was distributed to 80 English teachers in Taiwanese primary schools. The findings show that the majority of the participants agree that the mixed-ability approach can help students fit into society; however, over one third of the teachers did not agree that students can learn effectively in MAT and over half claimed that they had difficulties catering for different individuals, especially the ablest and weakest students. Furthermore, they state that the current class size, learning hours, equipment and other additional factors cause difficulties for MAT (mixed ability teaching).
\end{abstract}

Keywords: primary schools, mixed-ability teaching, mixed ability class, English teaching

\section{Introduction}

Moon (2005, p. 27) points out that all classes have children with different abilities and characteristics. Teachers need to find different ways to cope with this variety. Teachers frequently complain that some students do not participate in class activities class but they disturb the class. Students complain that the lessons are too challenging. Furthermore, some teachers state that there are great differences in levels of English competence among students in their classes; for example, some students do not know the alphabet, while others are able to read the Harry Potter books. Chen (2013) point out that many students in Taiwan have extra English lessons after school and this situation causes students to have starkly divergent levels of English competence. Consequently, teachers face great difficulties in their work. Some teachers know that their students have quite different abilities in English, but they usually use the same worksheets and activities in teaching. They may seldom design different levels of worksheets for students. As a result, the ablest and the weakest students are prone to feeling bored and neglected in class.

There is fierce debate about streamed classes and mixed ability classes (MAC) in Taiwanese education. People in Taiwan care about academic performance and that streamed classes can promote student academic performance more than MAC (Chang, 2008; Chen, 2006; Oladejo, 2006). However, streamed classes cause educational injustice in Taiwanese society, so mixed ability groups have been introduced into most primary and secondary schools in Taiwan. The Ministry of Education (2004) also suggests that some adjustments should be made for mixed ability teaching, such as smaller class sizes, the promotion of mixed ability teaching MAT (mixed ability teaching), and the promotion of other alternative methods of learning. However, the government has a positive attitude towards MAT (mixed ability teaching) and offers solutions to solve the difficulties that teachers meet in MAT (mixed ability teaching). From the researcher's own experience, there are still many problems with English education in Taiwan. This has therefore prompted the interest in investigating Taiwanese primary school English teachers' towards the relevant issues concerning MAT (mixed ability teaching).

\section{Literature Review}

\subsection{What Is Meant by Mixed Ability?}

According to Barker (2003), everyone is different and unique in the world. Fisher (2001) also notes that human society was born in a mixed-ability world and that there are differences among people. Furthermore, Ainslie 
(1994) claims that mixed abilities between different individuals is not confined to differences in the capacity to learn but also in a number of separate areas. Some of these variations are related specifically to the potential for language learning, but many are much broader and have greater significance for classroom activity. Ainslie (1994) further points out that these areas include motivation, interest, needs, linguistic ability, general educational background, learning style, age, external pressures, and the time available to study, and anxiety.

\subsection{Why Mixed Ability?}

There are many advantages to the mixed ability approach in teaching; these advantages are presented below.

\subsubsection{Avoids Labelling and Offers Educational Justice}

MAT helps avoid labelling students and can also benefit teachers. As for students, the major advantage is that it allows students to gain an equal learning opportunity, and this can improve their motivation and self-evaluation, and avoid a sense of failure (Hallam \& Ireson, 2005). With regard to teachers, they state that teachers can also avoid being labelled as less able teachers if they teach to the lowest level. Furthermore, educational justice can be promoted by this approach. Kelly (1978) and Bremner (2008) emphasizes that education is not a kind of competitive game or a race with a limited number of prizes; therefore, every child should be treated equally and every child's achievement should be accepted equally.

\subsubsection{Fosters Personal and Social Development}

Education does not only aim to teach students, but also to help them to identify and develop their personality. Mixed ability classes can foster personal and social development in students (Tomlinson, 2001). This approach gives students security, confidence, a sense of individual responsibility, and can also encourage self-sufficiency that will not only, benefit students but the whole of society. Furthermore, if all students work together well, this can lead them to respect each other's individual differences, and to learn to tolerate others. The mixed ability approach provides strong support to what is called humanism, which, Williams and Burden (1997) emphasize that it develops a person totally and not only his cognitive skills.

\subsubsection{Caters to Different Needs Effectively}

Another advantage of mixed ability education is that teachers can effectively cater for individual needs (Boaler, 2008). In MAT (mixed ability teaching), teachers are more engaged with the idea that students have different learning styles and intelligences, and so they design a variety of activities to cater to their needs. In his Multiple Intelligence Theory, Gardner (1984) states that everyone has eight different potential intelligences: linguistic intelligence, visual spatial intelligence, logical-mathematical intelligence, bodily-kinaesthetic intelligence, musical intelligence, interpersonal intelligence, intrapersonal intelligence, and naturalist intelligence. Some people have higher levels of ability in one or two intelligences, but lower levels in other intelligences. Tanner (2001) claims that teachers can apply Multiple Intelligences theory when designing language skills activities since students learn in different ways. Ireson, Hallam, and Hurley (2005) comments that the mixed ability approach can assist in catering for different learning styles and intelligences and it also supports the ideas of Multiple Intelligence theory.

\subsubsection{Creates a Better Classroom Atmosphere}

MAT (mixed ability teaching) offers a better classroom atmosphere. MAT (mixed ability teaching) provides a happy atmosphere as it prompts a feeling of security, prevents students from being prejudged, and respects those with different talents, achievements and backgrounds (Tomlinson, 2001). They also point out that co-operation and high levels of motivation can be fostered in a good classroom atmosphere, both of which are real advantages for students.

\subsection{What Is Mixed Ability Teaching?}

Every class is made up of a group of individuals, each of them different in knowledge and ability. Ridley (1982, p. 37) claims that: 'All teaching in schools is mixed ability teaching.' When a teacher has responsibility for teaching more than one child at a time, he or she is faced with the problem of designing learning activities that take account of individual differences within the group. Bailey (1976) and Prodromou (1996) believe that the teacher who is involved in MAT (mixed ability teaching) pays more attention to individuals and works more with individuals rather than with a class or group. Collier (1982, p. 25) comments that mixed ability education is a necessary step in the direction of greater educational justice and that it also enriches the education of students and improves educational attainment. The mixed ability approach is adopted widely by many education systems.

\section{Methods}

This study used a questionnaire to gather broad data about teachers' attitudes towards MAT (mixed ability 
teaching) and MAC (mixed ability class) in primary schools. Questionnaires are useful in gaining data. In this regard, (Mertens, 2010; Fowler, 2008) state that questionnaires emphasise an individual's self-reporting of their knowledge, belief or attitude. Moreover, McMillan and Schumacher (2009) state that questionnaire can be used to describe people's background information, to deal with relationships between a study's variables, and to explain information provided. Because the purpose of this study was to explore teachers' attitudes, a questionnaire was used. Furthermore, there are a number of practical reasons why I chose to employ a questionnaire for this study. Firstly, questionnaires can be sent to respondents from the researcher at a distance, which was beneficial in my present situation: the questionnaires were sent to participants over the internet and their responses were also sent the back in the same way. On this point, Howson (2002) indicates that administering questionnaire-based research via email is easy, requiring only a minimal technical competency, and increasing time and cost efficiency. Secondly, questionnaires enable the collection of opinions, ideas and experiences from a wide number of potential participants (Mertens, 2010). Using a questionnaire also allows such data to be collected at the convenience of the respondents (Fowler, 2008). Furthermore, questionnaires can elicit many different opinions (Cohen, Manion, \& Morrison, 2011). Finally, many teachers in Taiwan are familiar with the questionnaire format, as these are commonly used to collect data in educational research.

\subsection{Materials}

The questionnaire was the primary instrument used in the survey portion of this study. The questionnaire consisted of two main sections, A and B. There was an introduction before section A, in which I briefly introduced the research plan and the invitation to participants to join the research.

In section A, participants were asked to give background information and teaching circumstances. From these questions, I wanted to understand the MAT (mixed ability teaching) experience of Taiwanese primary school teachers and their teaching circumstances.

Section B consisted of one ranked question and twenty-two closed questions to explore attitudes about the mixed ability approach in TEFL. These questions included both the advantages and challenges of the mixed-ability approach and used a three-point Likert Scale ("agree", "not sure" and "disagree").

\subsection{The Research Procedure}

\subsubsection{Piloting}

Before distributing the questionnaires to the participants, I piloted my questionnaire on two TESOL classmates from Taiwan whose teaching backgrounds are similar to the participants, which ensured that all questions and instructions would be clear. Furthermore, the questions were constructed so as to obtain relevant responses whilst avoiding any ambiguities or misunderstandings. With their help, a number of problems were found and amended, such as inappropriate vocabulary, ambiguous questions, unclear layout, and confusing question style. One of my colleagues pointed out that every teacher needed to answer many questionnaires and that some of them are not proficient in English. Further, Gillham (2000) mentions that in order to have a higher response rate, it is better to translate questionnaires into the native language of the participants. Hence, I translated my questionnaire into Chinese and asked two colleagues who teach Chinese to pilot the Chinese questionnaire. Because of their suggestions, I changed some words usage and used the "list function" to make answering questionnaires simple on a computer. This procedure took me approximately two weeks to conclude.

\subsubsection{Participants}

After piloting and adjusting the questionnaire several times, the questionnaire was sent via email to the participants. The participants were given two weeks to complete the questionnaire. Because of confidentiality, I asked all participants to send the questionnaires back directly over the internet. The participants in this study were eighty English teachers in Taiwanese primary schools. All the eighty English had experience of teaching mixed ability classes.

\section{Results and Discussions}

\subsection{Teachers' Background and Teaching Circumstances}

The results in table 1 show that $32 \%$ of teachers in this study have not had any mixed ability teacher training. Furthermore, new teachers normally have had more training than older teachers. It is a pity that this research could not find any further information to support this viewpoint. There were not enough professional English teachers in Taiwan when the English education reform was implemented. The government started to train more teachers and held more training courses, but some teachers have never had any training before or while in service. The government should continue to offer more training in MAT (mixed ability teaching). This clearly shows that 
there is a need to improve MAT (mixed ability teaching) in Taiwan.

Table 1. Teachers' teaching experience and teaching training $(\mathrm{N}=62)$

\begin{tabular}{lllll}
\hline Statement & Response & & \\
\hline 1 & English teaching experience & Less than 5 years & $6-12$ years & $13-20$ years \\
& & $35(57 \%)$ & $25(40 \%)$ & $2(3 \%)$ \\
\hline 2 & $\begin{array}{l}\text { Experience of teacher } \\
\text { training courses especially }\end{array}$ & Yes (20) $32 \%$ & in Pre-service (23) & \\
focusing on how to teach & in-service (13) & \\
MAC & & Both(6) & \\
\end{tabular}

Results in Table 2 show that most teachers who use MAC (mixed ability class) (90\%), have two sessions for a certain class in a week (85\%), and have more than thirty students in their class (81\%). Reid et al., (1981) mention that large class sizes cause difficulties in MAT (mixed ability teaching) and that the optimal class size is 20-25. Although the government in Taiwan claims to have reduced the number of students per class, most teachers still have overly large class sizes, which present difficulties for teaching. Furthermore, MAT (mixed ability teaching) involves formidable preparation and written work, but because there are no assistants, even for such large classes, there are further difficulties with MAT (mixed ability teaching). Moreover, Salli-Copur (2005) also mention that time constraints are another factor that cause problems with MAT (mixed ability teaching). The aim was to promote students interest in learning English at the outset of English education; then students were asked to master listening, speaking reading and writing in English. Two English lessons per week are too few to enable students to meet such English skills. Therefore, the teaching environment makes MAT (mixed ability teaching) more difficult and ineffective.

Table 2. Teachers' teaching circumstances $(\mathrm{N}=62)$

\begin{tabular}{|c|c|c|c|c|}
\hline \multicolumn{2}{|c|}{ Statement } & \multicolumn{3}{|l|}{ Response } \\
\hline \multirow[t]{3}{*}{3} & \multirow[t]{3}{*}{ Experience of teaching } & Streamed class & (4) & $6 \%$ \\
\hline & & Mixed ability class & (56) & $90 \%$ \\
\hline & & Both & (2) & $4 \%$ \\
\hline \multirow[t]{5}{*}{4} & \multirow[t]{5}{*}{ Your current class size } & $<25$ & (12) & $19 \%$ \\
\hline & & $25-30$ & (9) & $14 \%$ \\
\hline & & $31-35$ & (33) & $53 \%$ \\
\hline & & $36-40$ & (4) & $7 \%$ \\
\hline & & $>40$ & (4) & $7 \%$ \\
\hline \multirow[t]{4}{*}{5} & \multirow{4}{*}{$\begin{array}{l}\text { How many } 40 \text {-minute lessons do } \\
\text { your students have each week? }\end{array}$} & 1 & (3) & $5 \%$ \\
\hline & & 2 & (53) & $85 \%$ \\
\hline & & 3 & (5) & $8 \%$ \\
\hline & & more than 3 & (1) & $2 \%$ \\
\hline
\end{tabular}

\subsection{Attitudes about Mixed-Ability Approach in TEFL}

According to the results show's in Table 3, the majority (94\%) think that their most important educational aims are to improve student interest and motivation to learn. Many teachers (87\%) think that improving academic 
performance is less important. It is good to know that many teachers are aware that fostering student's interest and motivation is important for young learners. From statement 62, one teacher points out that: "It is important to let students feel that English is interesting, or they will give up learning English early." However, teachers in Taiwan are under high pressure with regard to their pupils' academic performance, and teachers sometimes need to focus on specific teaching content to help students pass exams. It is a challenge for Taiwanese teachers to achieve both goals within their tight teaching schedules.

Table 3. Teachers' aims of teaching ( $\mathrm{N}=62)$

\begin{tabular}{|c|c|c|c|c|c|c|}
\hline & Statement & Response & & & & \\
\hline \multirow[t]{6}{*}{6} & Educational aims & $\begin{array}{l}\text { The most } \\
\text { important }\end{array}$ & $\begin{array}{l}\text { The } 2^{\text {nd }} \\
\text { important }\end{array}$ & $\begin{array}{l}\text { The } 3^{\text {rd }} \\
\text { important }\end{array}$ & $\begin{array}{l}\text { The } 4^{\text {th }} \\
\text { important }\end{array}$ & $\begin{array}{l}\text { The least } \\
\text { important }\end{array}$ \\
\hline & $\begin{array}{l}\text { to improve students' interest } \\
\text { and motivation in learning } \\
\text { English }\end{array}$ & $\begin{array}{l}37 \\
(60 \%)\end{array}$ & $\begin{array}{l}21 \\
(34 \%)\end{array}$ & $\begin{array}{l}2 \\
(3 \%)\end{array}$ & $\begin{array}{l}1 \\
(1.5 \%)\end{array}$ & $\begin{array}{l}1 \\
(1.5 \%)\end{array}$ \\
\hline & $\begin{array}{l}\text { to improve students' } \\
\text { academic performance }\end{array}$ & $\begin{array}{l}3 \\
(5 \%)\end{array}$ & $\begin{array}{l}1 \\
(2 \%)\end{array}$ & $\begin{array}{l}4 \\
(6 \%)\end{array}$ & $\begin{array}{l}16 \\
(26 \%)\end{array}$ & $\begin{array}{l}38 \\
(61 \%)\end{array}$ \\
\hline & $\begin{array}{l}\text { to improve students' general } \\
\text { language ability in all } \\
\text { language } 4 \text { skills }\end{array}$ & $\begin{array}{l}7 \\
(11 \%)\end{array}$ & $\begin{array}{l}15 \\
(24 \%)\end{array}$ & $\begin{array}{l}17 \\
(28 \%)\end{array}$ & $\begin{array}{l}23 \\
(37 \%)\end{array}$ & $\begin{array}{l}0 \\
(0 \%)\end{array}$ \\
\hline & $\begin{array}{l}\text { to improve students' oral } \\
\text { competence }\end{array}$ & $\begin{array}{l}8 \\
(13 \%)\end{array}$ & $\begin{array}{l}10 \\
(16 \%)\end{array}$ & $\begin{array}{l}26 \\
(42 \%)\end{array}$ & $\begin{array}{l}15 \\
(24 \%)\end{array}$ & $\begin{array}{l}3 \\
(5 \%)\end{array}$ \\
\hline & $\begin{array}{lr}\text { to improve } & \text { students' } \\
\text { personal and } & \text { social } \\
\text { development } & \end{array}$ & $\begin{array}{l}7 \\
(11 \%)\end{array}$ & $\begin{array}{l}15 \\
(24 \%)\end{array}$ & $\begin{array}{l}13 \\
(21 \%)\end{array}$ & $\begin{array}{l}7 \\
(11.5 \%)\end{array}$ & $\begin{array}{l}20 \\
(32.5 \%)\end{array}$ \\
\hline
\end{tabular}

From these results in Table 4, it is very surprising to discover that teachers in this study have quite divergent attitudes toward equal education opportunities in MAT (mixed ability teaching). Although teachers have quite opposite attitudes toward educational justice, many teachers share the belief that MAT can foster personal and social development in students. Most teachers (77\%) agree that students can learn to accept each others' differences because of MAT. Further, $84 \%$ teachers believe that MAT (mixed ability teaching) helps students to fit into society better and avoid labeling $(66 \%)$. Nevertheless, it is interesting to find out that over one third of teachers (39\%) doubt that the MAT (mixed ability teaching) approach can give students equal education opportunities. It might be that the great differences between students frustrate teachers in catering for individual needs, especially of the ablest and weakest students. Moreover, large class sizes and time constraints also cause difficulties to cater for individual needs effectively. Some teachers at the researcher's schools complained that the ablest students do not want to learn because the lesson is too easy for them and the weakest students do not have the ability to follow the lesson.

Table 4. Teachers' attitudes about mixed ability approach can offer better education justice ( $N=62)$

\begin{tabular}{|c|c|c|c|c|}
\hline & Statement & Agree & Not sure & Disagree \\
\hline 8 & $\begin{array}{l}\text { Students can obtain equal education opportunities in } \\
\text { MAT }\end{array}$ & $23(37 \%)$ & $15(24 \%)$ & $24(39 \%)$ \\
\hline 9 & $\begin{array}{l}\text { Students can learn to accept others' differences in } \\
\text { MAT }\end{array}$ & $48(77 \%)$ & $10(16 \%)$ & $4(7 \%)$ \\
\hline 10 & MAC helps students fit into society better & $52(84 \%)$ & $9(14 \%)$ & $1(2 \%)$ \\
\hline 11 & MAC can avoid labeling students & $39(66 \%)$ & $12(19 \%)$ & $11(15 \%)$ \\
\hline
\end{tabular}


From the data analysis in Table 5, most of the teachers (89\%) are aware that students have different learning styles, and that they $(87 \%)$ need to use various methods to cater for different needs. Although teachers know that students have different learning styles, only $13 \%$ of the teachers think that they can cater for different needs better with MAT (mixed ability teaching). Most teachers also have positive attitudes towards the ability of MAT to foster students' personal and social development. However, when it comes to effective learning, $58 \%$ of the teachers think that students can learn more effectively in a streamed class than in an MAC (mixed ability class). This might be because the teachers in this study had some difficulties with MAT (mixed ability teaching), so nearly one third of teachers believe that students cannot learn effectively in MAC (mixed ability class).

The majority ( $86 \%$ ) claim that they have difficulties catering for different needs and dealing with different paces of learning. Two thirds of the teachers think that MAT (mixed ability teaching) focuses on middle level students. Furthermore, $37 \%$ of the teachers think that the ablest students are neglected easily by MAT (mixed ability teaching), while $45 \%$ of the teachers claim that the weakest students are easily neglected by MAT (mixed ability teaching). This could be because teachers in Taiwan still do not know enough about, or do not have enough information on the use of -MAT (mixed ability teaching) approach. Furthermore, the teaching environment in Taiwan, such as large class sizes, time constraints, and the great differences between students, also lessens the effectiveness of MAT (mixed ability teaching).

Table 5. Teachers' attitudes about students' learning abilities, style and teachers responsibilities ( $N=62)$

\begin{tabular}{lllll}
\hline & Statement & Agree & Not sure & Disagree \\
\hline 12 & $\begin{array}{l}\text { I am aware that students have different learning } \\
\text { styles }\end{array}$ & $55(89 \%)$ & $5(8 \%)$ & $2(3 \%)$ \\
\hline 13 & $\begin{array}{l}\text { Teachers should use different strategies to cater for } \\
\text { students' different learning styles }\end{array}$ & $54(87 \%)$ & $5(8 \%)$ & $3(5 \%)$ \\
\hline 14 & $\begin{array}{l}\text { It is students' responsibility to accommodate } \\
\text { themselves to teachers' teaching methods }\end{array}$ & $40(65 \%)$ & $15(24 \%)$ & $7(11 \%)$ \\
\hline 15 & $\begin{array}{l}\text { Teachers can cater for different needs better in } \\
\text { MAT }\end{array}$ & $8(13 \%)$ & $11(18 \%)$ & $43(69 \%)$ \\
\hline 7 & Most students learn effectively in MAC & $13(21 \%)$ & $25(40 \%)$ & $24(39 \%)$ \\
\hline 28 & Most students learn effectively in streamed class & $36(58 \%)$ & $20(32 \%)$ & $6(10 \%)$ \\
\hline 16 & $\begin{array}{l}\text { It is hard to cater for different learning paces in } \\
\text { MAT }\end{array}$ & $53(86 \%)$ & $5(8 \%)$ & $4(6 \%)$ \\
\hline 17 & MAT focuses on middle level students & $41(66 \%)$ & $12(19 \%)$ & $9(15 \%)$ \\
\hline 18 & The ablest students are neglected easily in MAT & $23(37 \%)$ & $14(23)$ & $25(40 \%)$ \\
\hline 19 & The weakest students are neglected easily in MAT & $28(45 \%)$ & $19(31 \%)$ & $15(24 \%)$ \\
\hline
\end{tabular}

According to Table 6, Younger learners are not highly motivated to learn a language, so teachers need to build a better learning atmosphere to promote the motivation to learn. Westwood \& Arnold (2004) claim that MAT (mixed ability teaching) can promote students motivation and create a better classroom atmosphere, but many Taiwanese English teachers have opposite views on these points. They mention that one of their difficulties in handling MAC (mixed ability class) is the different levels of English competency. One teacher in this study mentions that some of the ablest and weakest students do not pay attention to the teachers and disturb other students. This might be why some teachers in this study do not agree that MAT (mixed ability teaching) offers a better classroom atmosphere or promote students motivation. As mentioned above, students have extra English classes in private language institutions, and this widens the gap in English competence. 
Table 6. Teachers' view about learning atmosphere in MAT approach $(\mathrm{N}=62)$

\begin{tabular}{lllll}
\hline & Statement & Agree & Not sure & Disagree \\
\hline 22 & $\begin{array}{l}\text { Teachers' expectations can influence students' } \\
\text { performance }\end{array}$ & 57 & 3 & 2 \\
& $(92 \%)$ & $(5 \%)$ & $(3 \%)$ \\
\hline 20 & There is a better classroom atmosphere in MAC & 22 & 27 & 13 \\
& & $(35 \%)$ & $(44 \%)$ & $(19 \%)$ \\
\hline 21 & MAT promotes students' motivation & 14 & 32 & 16 \\
& & $(22 \%)$ & $(52 \%)$ & $(26 \%)$ \\
\hline
\end{tabular}

The results in Table 7 shows that many teachers in the current study (87\%) agree that using groups can help students to learn effectively and that $61 \%$ also believe that they have enough knowledge and ability to form the groups. However, just over one third of the teachers (35\%) still have difficulties maintaining classroom discipline and designing mixed-level worksheets for students. Ireson, Hallam, and Hurley (2005) claim that using groups in MAT (mixed ability teaching) can effectively cater for different needs. However, Taiwanese students are used to teacher-centred classes and need training to work in groups. Ireson, Hallam, and Hurley (2005) claims that not only teachers but also students need to adjust to the new approach. Hess (2001) points out that managerial techniques and workable routines can help teachers. It means that more knowledge and information about managing discipline can be introduced to teachers. For statement 27, nearly half of the teachers agree that it is difficult to design different levels of worksheets. However, to improve the situation it would be helpful to introduce more useful MAT (mixed ability teaching) techniques to Taiwanese teachers, and they should also be given the responsibility to learn more about the MAT (mixed ability teaching) approach.

Table 7. Teachers' views on using groups and mixed level materials in teaching $(\mathrm{N}=62)$

\begin{tabular}{lllll}
\hline & Statement & Agree & Not sure & Disagree \\
\hline 23 & It is hard to group students. & $15(24 \%)$ & $9(15 \%)$ & $38(61 \%)$ \\
24 & Using group work helps learners learn effectively. & $54(87 \%)$ & $8(13 \%)$ & $0(0 \%)$ \\
25 & $\begin{array}{l}\text { A teacher-centred classroom helps learners learn } \\
\text { effectively. }\end{array}$ & $8(13 \%)$ & $25(40 \%)$ & $29(47 \%)$ \\
26 & It is hard to control discipline while using group work. & $22(35 \%)$ & $12(20 \%)$ & $28(45 \%)$ \\
27 & It is difficult to design different level worksheets. & $29(47 \%)$ & $9(14 \%)$ & $24(39 \%)$ \\
\hline
\end{tabular}

\section{Conclusion}

This study discussed the advantages, challenges and teaching strategies of the MAT (mixed ability teaching) approach and employed a questionnaire to explore the attitudes towards MAT (mixed ability teaching) of sixty-two teachers. Most of the teachers (94\%) in the study claimed that the most important educational aim is to promote student interest in and motivation to learn English. Furthermore, the majority of the participants agree that the mixed-ability approach can help students fit into society; however, over one third of the teachers did not agree that students can learn effectively in MAT (mixed ability teaching) and over half claimed that they had difficulties catering for different individuals, especially the ablest and weakest students. According to Collier (1982), mixed ability is a positive method of teaching and offers educational justice, giving every student equal opportunities in education. Although many problems still need to be overcome, teachers have the potential to make important changes in the classroom. They have been known to use different activities or techniques to enrich their teaching, but, with so many aspects to be addressed, teachers still need to improve their techniques.

\section{References}

Ainslie, S. (1994). Mixed-Ability Teaching: Meeting Learners' Needs. London: Centre for Information on Language Teaching and Research.

Bailey, C. (1976). Mixed ability teaching and the defence of subjects. Cambridge Journal of Education, 6, 24-31. http://dx.doi.org/10.1080/0305764760060104 
Barker, A. (2003). Bottom: A Case Study Comparing Teaching Low Ability and Mixed Ability Year 9 English Classes. English in Education, 37(1), 4-14. http://dx.doi.org/10.1111/j.1754-8845.2003.tb00586.x

Boaler, J. (2008). Promoting "relational equity" and high mathematics achievement through an innovative mixed ability approach. British Educational Research Journal, 34(2), 167-194. http://dx.doi.org/10.1080/01411920701532145

Bremner, S. (2008). Some thoughts on teaching a mixed ability class. Scottish languages review, 18, 1-10.

Chang, Y. F. (2008). Parents' attitudes toward the English education policy in Taiwan. Asia Pacific Education Review, 9(4), 423-435. http://dx.doi.org/10.1007/BF03025660

Chen, A. H. (2013). An Evaluation on Primary English Education in Taiwan: From the Perspective of Language Policy. Journal of English Language Teaching, 6, 158-165. http://dx.doi.org/10.5539/elt.v6n10p158

Chen, Y. L. (2006). The influence of partial English immersion programs in Taiwan on kindergartener's perceptions of Chinese and English languages and cultures. Asian EFL Journal, 8(1), 1-44.

Cohen, L., Manion, L., \& Morrison, K. (2011). Research Methods in Education (7th ed.). London: Routledge Falmer.

Collier, F. (1982). A Retreat from Mixed ability Teaching. In M. Sands, \& T. Kerry (Eds.), Mixed Ability Teaching (pp. 25-36). London: Croom Helm Ltd.

Fisher, R. (2001). Teaching Children to Learn. Cheltenham: Nelson Thornes Ltd.

Fowler, F. (2008). Survey research methods. Thousand Oaks: Sage.

Gardner, H. (1993). Frames of mind: The Theory of Multiple Intelligences. London: Fontana Press.

Gillham, B. (2000). Developing a questionnaire. London: Continuum.

Hallam, S., \& Ireson, J. (2005). Secondary School Teachers' pedagogic practices when teaching mixed and structured ability classes. Research Papers in Education, 20(1), 3-24. http://dx.doi.org/10.1080/0267152052000341318

Hess, N. (2001). Teaching Large Multilevel Class. Cambridge: Cambridge University Press. http://dx.doi.org/10.1017/CBO9780511732966

Hewson, C., Yule, P., Laurent, D., \& Vogel, C. (2002). Internet research methods. London: SAGE.

Ireson, J., Hallam, S., \& Hurley, C. (2005). What are the effects of ability grouping on GCSE attainment? British Educational Research Journal, 31(4), 443-458. http://dx.doi.org/10.1080/01411920500148663

Kelly, V. A. (1978). Mixed-Ability Grouping: Theory and Practice. London: Harper and Row.

McMillan, J. H., \& Schumacher, S. (2009). Research in education: Evidence-Based Inquiry. New York: Pearson Education, Inc.

Mertens, D. M. (2010). Transformative research and evaluation. Journal of Qualitative Inquiry, 6, 469-474. http://dx.doi.org/10.1177/1077800410364612

Ministry of Education. (2004). Major events of the education. Retrieved from http://epaper.edu.tw/021/important.htm

Moon, J. (2005). Children Learning English. Oxford: Macmillan Education.

Oladejo, J. (2006). Parents' attitudes towards bilingual education policy in Taiwan. Bilingual Research Journal, $30(1), 147-170$.

Prodromou, L. (1996). Mixed Ability Classes. Harlow: Pearson Education Ltd.

Reid, M., Clunies-Ross, L., Goacher, B., \& Vile, C. (1981). Mixed Ability Teaching: Problems and Possibilities. Educational Research, 24(1), 3-10.

Ridley, K. (1982). Mixed ability Teaching in the Primary School. In M. Sands, \& T. Kerry (Eds.), Mixed Ability Teaching (pp. 37-46). London: Croom Helm Ltd.

Salli-Copur, D. (2005). Coping with the Problems of Mixed Ability Classes. The Internet TESL Journal, 11(8).

Tanner, R. (2001). Teaching intelligently. English Teaching Professional, 20, 40-41.

Tomlinson, C. A. (2001). How to Differentiate Instruction in Mixed-Ability Classrooms. Alexandria, Virginia: Association for Supervision and Curriculum Development (ASCD). 
Westwood, P., \& Arnold, W. (2004). Meeting individual needs with young learners. ELT Journal, 58(4), 375-378. http://dx.doi.org/10.1093/elt/58.4.375

Williams, M., \& Burden, R. L. (1997). Psychology for Language Teachers: A Social Constructivist Approach. Cambridge: Cambridge University Press. http://dx.doi.org/10.1177/0261927X970163001

\section{Copyrights}

Copyright for this article is retained by the author(s), with first publication rights granted to the journal.

This is an open-access article distributed under the terms and conditions of the Creative Commons Attribution license (http://creativecommons.org/licenses/by/3.0/). 